\title{
EFFECT OF CLIMATE CHANGE ON TEST-DAY MILK YIELD OF HOLSTEIN COWS MAINTAINED IN THE NILE DELTA OF EGYPT
}

\author{
A.A. Nigm ${ }^{1}$, R.R. Sadek ${ }^{1}$, Sherien A. Yassien ${ }^{2}$, M.A.M. Ibrahim ${ }^{1}$ and M. A. El-Wardani ${ }^{2}$ \\ 1- Department of Animal Production, Faculty of Agriculture, Cairo University, Giza, Egypt, 2 - Department of \\ Production Systems Research, Animal Production Research Institute, Agricultural Research Center, Dokki, \\ Egypt
}

\section{SUMMARY}

To evaluate the effect of climate change on milk yield of Holstein cattle maintained in the Delta region of Egypt, meteorological data covering the period 2000-2014 were obtained from the Central Laboratory for Agricultural Climate. Data of test-day milk yield (TDMY) comprised 109759 records, were collected from four herds (5546 Holstein cows) covering the same period of meteorological data. The four herds represented different parts of the Delta region: west of the Delta (Dina farm, El-Behera governorate, H1 and H2), middle (El- Sharkia governorate, Sami Asaad farm, H3) and east of Delta (El- Karada farm, Kafr El-Sheikh governorate, H4). Daily management practices were almost comparable in the four studied herds, except for the housing systems.

Preliminary analysis of meteorological data during the period (2012-2014) revealed that the air temperature increased $(P<0.05)$ by $19.8 \%$, during June-September, and by $3.1 \%$ for all the year round, relative to the period (2000 to 2011). Temperature humidity index (THI) showed a similar trend to air temperature, increased $(P<0.05)$ by $10.5 \%$, during June-September, and by $2.3 \%$ for all the year round, during the same year periods. THI values were more than the minimum threshold of heat stress $(\leq 74)$, throughout the June-September, while less than this threshold during the rest of the calendar year. TDMY decreased $(P<0.05)$ when THI was $>74$. TDMY, also decreased $(P<0.05)$ by 6.1\% in the period from 2012-2014 compared to 2000-2011.

It could be concluded that a marked change in the climate of the Delta region of Egypt expressed in the rise of THI values. This rise started the year 2011 up to 2014. This change negatively affects milk production as measured by TDMY.

Keywords: climate change, test-day milk yield, Holstein cows, delta region, Egypt

\section{INTRODUCTION}

Many reports emphasized that there is a rise in the temperature of earth's climate, which is known as global warming, expected to increase ranging from $1.4^{\circ} \mathrm{C}$ to $3.0^{\circ} \mathrm{C}$ by the year 2050 (Perkins, 2012 and Yirka, 2012). Global warming is a critical issue due to its direct impact on agriculture and water resources worldwide. Climate change may exert negative impacts on livestock welfare, performance and health (Houghton et al., 2001; Nardone et al., 2006 and Singh et al., 2012). In Africa, the agriculture sector will suffer the most from the adverse effects of climate change because the major proportion of agricultural production is from livestock (Nesamvuni et al., 2012).

Elevation of air temperature (AT), particularly, in humid areas will increase heat stress of the majority of the cattle population. It is a fact that about two third of the world's cattle populations are located in hot zones under the influence of high AT and high relative humidity (Wolfenson et al., 2000 and Wolfenson, 2009). This represents a major constraint on animal productivity (Marai et al., 2008). Egypt is one of Mediterranean basin countries. Mediterranean regions are most vulnerable to climate change (Olesen and Bindi, 2002 and Metzger et al., 2006).

Heat stress is a combination of many environmental factors (West, 2003 and Bohmanova et al., 2006). Temperature humidity index (THI) is the most common parameter describing the microenvironment and level of heat stress (Bohmanova et al., 2006). THI value of $>74$ means that animals are suffering from heat stress (Mader et al., 2006).

No published reports are available on the effect of global warming on milk production of Holstein cows under the Egyptian conditions. However, Hafez et al. (2011) studied physiological and hormonal responses of Egyptian buffalo to different climatic conditions. Also, Elbeltagy et al. (2015) studied the biological and mathematical responses of desert sheep and goats to both natural and acute heat stress in Egypt.

Holstein is the most recognized and common dairy breed (Elischer, 2014); the most predominant exotic breed in the commercial herds in Egypt; and the most vulnerable to heat stress and the current climate change (Thornton et al., 2009). Thus, the objectives of this study were to describe the climate change in the Nile Delta region of Egypt during the period from 2000-2014; and to assess its effect on test day milk yield (TDMY) of Holstein cows maintained in this region.

\section{MATERIALS AND METHODS}

\section{Location and herd management}

The present study was based on the data collected from four large dairy herds; the first two herds were located at Dina Dairy farm for Agricultural 
Investment, El- Behera governorate, west of the Delta, at a latitude angel of $30.14^{\circ}$ and a longitude angle of $30.33^{\circ}$ (H1 and H2). Sami Asaad farm, Sharkia governorate (Middle of the Delta), at a latitude angel of $30.32^{\circ}$ and a longitude angle of $31.39^{\circ}$ maintained the third herd (H3). The fourth herd (H4) was maintained at El-Karada farm, Kafr ElShiekh governorate (East of Delta), at a latitude angel of $31.14^{\circ}$ and a longitude angle of $30.57^{\circ}$. Dina and Sami Assad are commercial farms, while El-Karada farm belongs to the Animal Production Research Institute, Agricultural Research Center, Ministry of Agriculture and Land Reclamation, Egypt.

Management practices in the four herds were almost comparable. Nutritional requirements were offered according to NRC (2001). Rations were fed thrice a day and water was made available all the day time. Cows were machine milked 2-3 times daily and daily milk yield was recorded. Heifers and cows displayed estrous symptoms were inseminated with frozen semen from Holstein bulls, out of the top 100 A.I. bulls of Holstein in U.S.A. and Canada, except for El-Karada farm where semen was available from bulls raised and maintained at Sakha A.I. center, Kafr El-Shiekh governorate. Cows of the studied herds were housed in open yards shaded with corrugated metal sheets. Yards of $\mathrm{H} 1, \mathrm{H} 2$ and $\mathrm{H} 3$ were equipped with cooling system while yards of $\mathrm{H} 4$ were not.

\section{Data collection}

Meteorological data (air temperature, AT and relative humidity, $\mathrm{RH}$ ) of the three governorates under study (El- Behera, El-Sharkia and Kafr ElSheikh) were obtained from the Central Laboratory for Agricultural Climate, Agricultural Research Center, Ministry of Agriculture and Land Reclamation, Egypt. The data were obtained from three meteorological stations located in the three governorates for the period from 2000-2014. Monthly THI values for the experimental sites were calculated using the equation of Mader et al. (2006):

$\mathrm{THI}=[0.8 \mathrm{x}$ air temperature $]+[(\%$ relative humidity/100) x (air temperature -14.4)] + 46.4.

THI values were divided into two classes, THI $\leq 74$ and THI $>74$. Based on the results of this study, the period from 2000-2014 was divided into two periods: the first period (R1) was from the year 2000 till 2011, with an average THI of 67.1 units, and the second (R2) with an average THI of 68.6 units throughout the year round. Difference between THI values of R1 and R2 became more pronounced when calculated for hot months (June-September; $70.4 \mathrm{vs}$. 77.8 units).

The test day milk yield (TDMY, kg) was the actual milk yield that was recorded once a month throughout the lactation period for all the cows milking in the four studied herds, over 15-years period (2000-2014, inclusive).

A total number of 109759 TDMY records for 5546 Holstein cows calved during the period from January 2000 to December 2014 were collected from the four above-mentioned herds. Distribution of records according to herd, parity, THI and year period is shown in Table (1).

Table 1. Distribution of test-day milk yield (TDMY) records of Holstein cows according to herd, parity, THI and year period

\begin{tabular}{lcc}
\hline Classification & $\begin{array}{c}\text { No. } \\
\text { of records }\end{array}$ & $\begin{array}{c}\text { \% } \\
\text { of records }\end{array}$ \\
\hline Herd: & & 38.8 \\
H1 (Dina 1) & 42635 & 21.2 \\
H2 (Dina 2) & 23272 & 36.4 \\
H3 (SamyAsaad) & 39941 & 3.6 \\
H4 (El-Karada) & 3911 & 45.3 \\
Parity: & & 26.0 \\
$\mathbf{1}$ & 49690 & 14.9 \\
$\mathbf{2}$ & 28586 & 7.5 \\
$\mathbf{3}$ & 16337 & 6.3 \\
$\mathbf{4}$ & 8209 & 84.2 \\
$\mathbf{2 5}$ & 6937 & 15.8 \\
THI: & & 65.9 \\
THI & & 34.1 \\
Year period: & 92375 & \\
R1(2000-2011) & 17384 & \\
\hline Total & & \\
\hline
\end{tabular}




\section{Statistical analysis}

Collected data were processed and analyzed using XLSTAT (2015). The following statistical model was applied to analyze test day milk yield trait.

$\mathrm{Y}_{\mathrm{i} \text { iklm }}=\mu+\mathrm{H}_{\mathrm{i}}+\mathrm{P}_{\mathrm{j}}+\mathrm{THI}_{\mathrm{k}}+\mathrm{R}_{1}+(\mathrm{HP})_{\mathrm{ij}}+(\mathrm{HTHI})_{\mathrm{ik}}+$ $(\mathrm{HR})_{\mathrm{il}}+(\mathrm{PTHI})_{\mathrm{jk}}+(\mathrm{PR})_{\mathrm{jl}}+(\mathrm{THIR})_{\mathrm{kl}}+\mathrm{e}_{\mathrm{ijk} \mathrm{km}}$

Where,

$\mathrm{Y}_{\mathrm{ijk} \mathrm{l}}=$ an observation of the test day milk yield trait,

$\mu=$ the overall mean,

$\mathrm{H}_{\mathrm{i}}=$ effect of $\mathrm{i}^{\text {th }}$ herd, $(\mathrm{i}=1,2,3$ and 4$)$, where $1=$ Dina 1, $2=$ Dina 2, $3=$ SamyAsaad and $4=$ ElKarada,

$P_{j}=$ effect of $j^{\text {th }}$ lactation order, $(j=1,2,3,4$ and $\geq 5)$, $\mathrm{THI}_{\mathrm{k}}=$ effect of the $\mathrm{k}^{\text {th }} \mathrm{THI},(\mathrm{k}=1$ and 2$)$, where $1=$ $\mathrm{THI} \leq 74$ and $2=\mathrm{THI}>74$,

$\mathrm{R}_{1}=$ effect of $1^{\text {th }}$ year period, $(1=1$ and 2$)$, where $1=$ 2000-2011 and $2=2012-2014$,

$\mathrm{HP}_{\mathrm{ij}}=$ effect of the interaction between herd and lactation order,

$\mathrm{HTHI}_{\mathrm{ik}}=$ effect of the interaction between herd and THI,
$\mathrm{HR}_{\mathrm{il}}=$ effect of the interaction between herd and year period,

$\mathrm{PTHI}_{\mathrm{jk}}=$ effect of the interaction between lactation order and THI,

$\mathrm{PR}_{\mathrm{jl}}=$ effect of the interaction between lactation order and year period,

$\mathrm{THIR}_{\mathrm{kl}}=$ effect of the interaction between THI and year period, and

$\mathrm{e}_{\mathrm{ijklm}}=$ random error, assumed to be $\operatorname{NID}\left(0, \sigma^{2}\right)$.

To measure the relative importance of each of AT and $\mathrm{RH}$, the variable importance for projection (VIP) was applied.

\section{RESULTS AND DISCUSSION}

\section{The variable importance for projection (VIP)}

The VIP measures the importance of each of the explanatory variables (AT and $\mathrm{RH}$ ) for the building up of THI. This allows identifying which of the explanatory variables contribute more to the projection model.

Table 2. Variable importance in the projection (VIP)

\begin{tabular}{lcc}
\hline Variable & VIP & Standard deviation \\
\hline Air temperature & 1.409 & 0.015 \\
Relative humidity & 0.122 & 0.130 \\
\hline
\end{tabular}

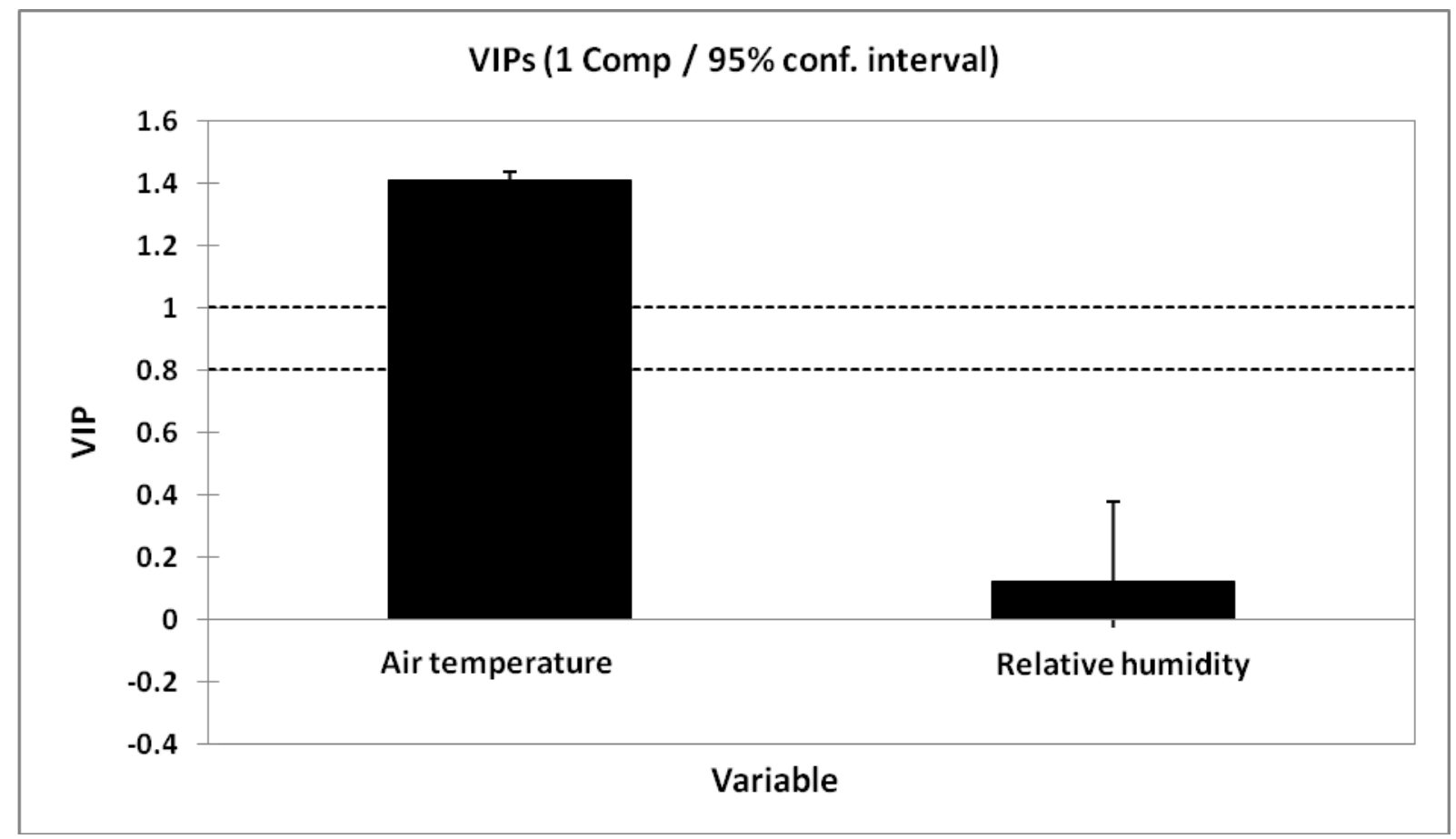

Fig.1.Variable importance in the projection (VIP)

It can be seen from Table (2) that, AT has higher VIP than RH. Two border lines for the VIP values are plotted to identify the VIPs that are greater than 0.8 (Figure.1). These thresholds, suggested by Wold (1995) and Ericksson et al. (2001), allow identifying the variable that is moderate $(0.8<\mathrm{VIP}<1)$ or highly influential (VIP>1). Air temperature is the highly influential variable in THI. Thus, THI values were used as an indicator of climate change in the present study.

\section{Climate change}

Analysis of the meteorological data of the period of 2000-2014 indicated that AT and THI increased $(\mathrm{P}<0.05)$ in R2 (2012-2014) compared to R1 (20002011). The patterns of increase for both AT and THI 
during the period of 2000-2014 were almost similar (Figure 2). Meteorological data also, showed similar trends for both parameters as measured during June to September of the year. THI values from January to May and from October to December were mostly less than the minimum threshold of heat stress $(\leq 74)$. Meanwhile, THI values increased (from the year 2011 and up to 2014) during June-September to more than 74 (Figure 3). THI values in R2 were higher than those in R1 by $10.5 \%$ during June-September and by $2.3 \%$ for all the year round. These findings clarified that there is a real increase in both AT and THI starting 2011 and up to 2014 in the Delta region of Egypt. Animals suffered from heat stress due to the high values of THI throughout the period from June to September.

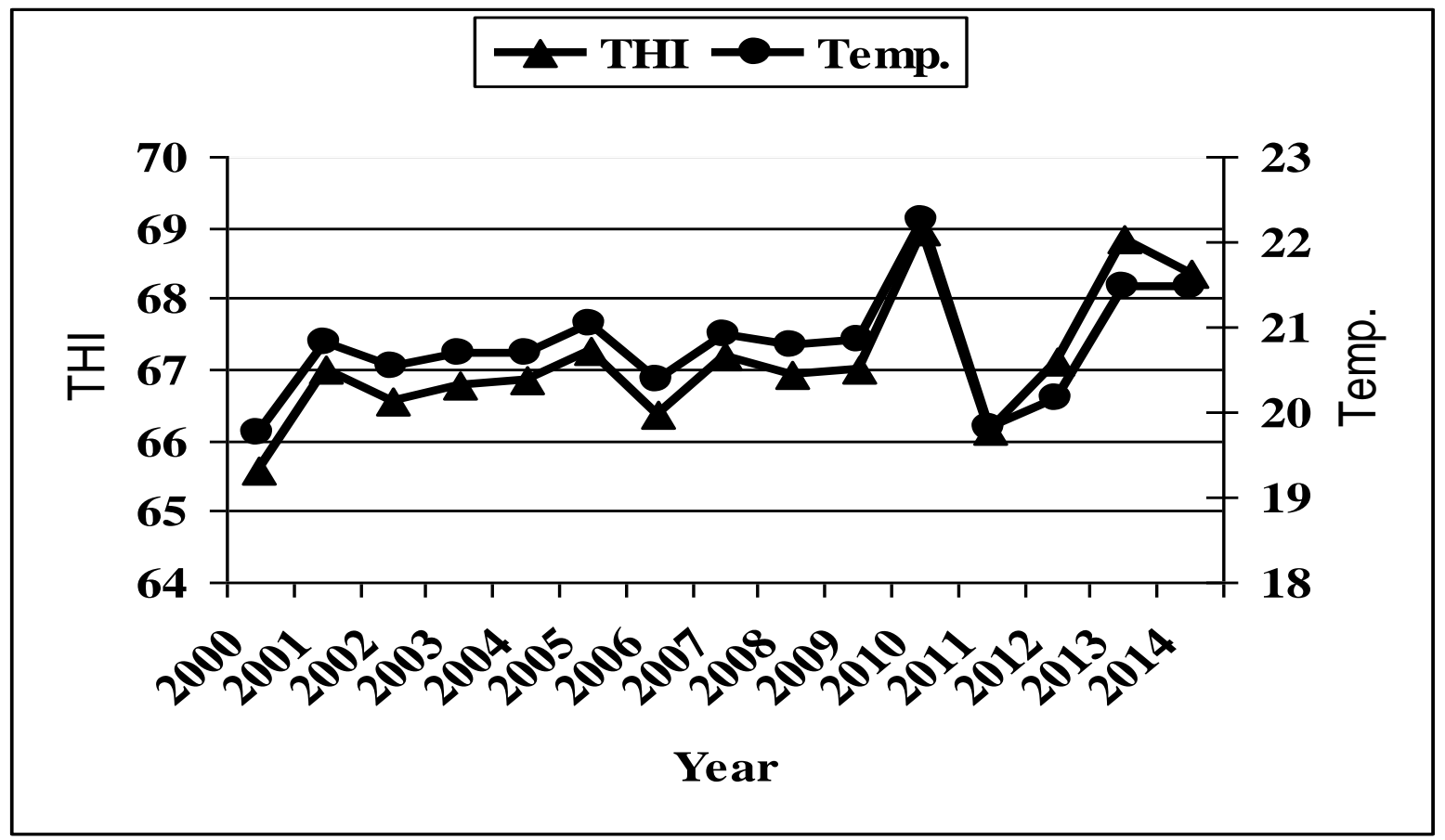

Fig. 2. Average air temperature (Temp.) and temperature humidity index (THI) in the three studied governorates for years 2000-2014

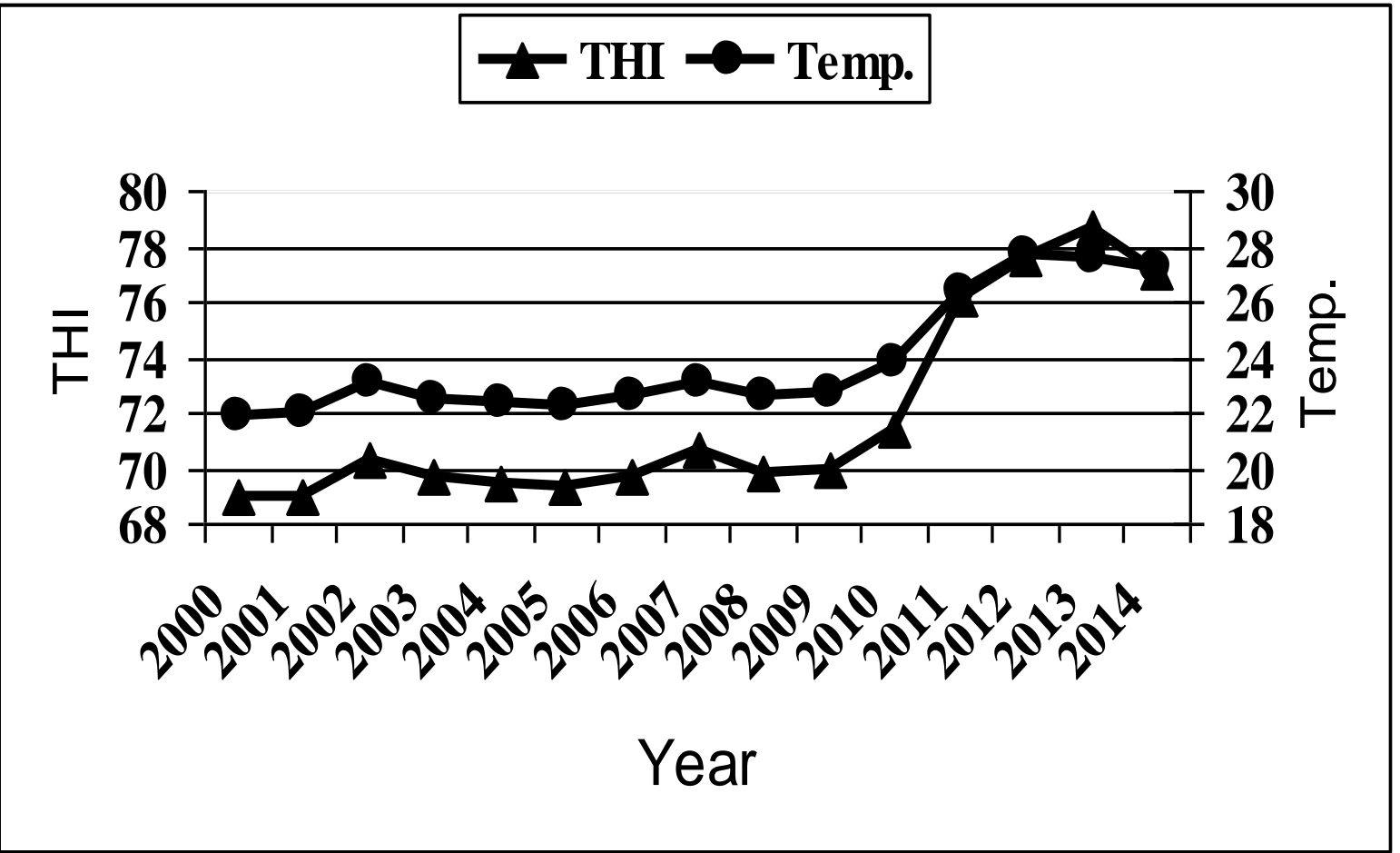

Fig. 3. Average air temperature (Temp.) and temperature humidity index (THI) in the three studied governorates for the months of June-September 2000-2014 


\section{Test-day milk yield (TDMY):}

Test-day milk yield (TDMY) was used to express the milk production of Holstein cows (Kaygisiz, 2013 and Santos et al., 2013). The overall mean of TDMY of the herds under study was $27.3 \pm 10.2 \mathrm{~kg}$. Table (3) shows that herd, parity, THI and year period showed a highly significant effect $(P<0.0001)$ on TDMY.

TDMY differed $(\mathrm{P}<0.05)$ among herds. H1 showed the highest value of TDMY, while H4 showed the lowest (Table 3). This difference most probably attributed to two main reasons. The first may be the genetic background of different herds (Thornton et al., 2009), and the second is the differences in micro-climate environment, especially the presence of cooling systems only in $\mathrm{H} 1, \mathrm{H} 2$ and H3.

The $3^{\text {rd }}$ and $4^{\text {th }}$ parities showed higher $(\mathrm{P}<0.05)$ TDMY compared to the other parities (Table 3 ). This result agrees with the findings of Guler et al. (2009) and Ríos-Utrera et al. (2013), who reported that total milk yield reached its maximum by the $3^{\text {rd }}$ and $4^{\text {th }}$ parities.

Obtained results (Table 3) indicated a negative relationship $(\mathrm{P}<0.05)$ between TDMY and THI, which means that heat stress reduces milk production. This agrees with the findings of Hounghton et al. (2001), reporting that heat stress has a negative impact on productivity and reproductive traits of Holstein cows. Similarly TDMY in R2, where THI was high, was less $(\mathrm{P}<0.05)$ than that of $\mathrm{R} 1$ by about $6.1 \%$. The negative impact of high temperature on milk production may be attributed to the reduction in feed intake (Rhoads et al., 2009) and/ or metabolic hormones (Rhoads et al., 2010 and Wheelock et al., 2010).

Table 3. Least squares means and standard errors $(\mathrm{LSM} \pm \mathrm{SE})$ of test-day milk yield (TDMY) as affected by herd, parity, THI, year period and their interactions

\begin{tabular}{|c|c|c|}
\hline Classification & $\mathbf{L S M} \pm \mathbf{S E}$ & $\mathbf{P}<$ \\
\hline Herd: & & $<0.0001$ \\
\hline H1 (Dina 1) & $32.1^{\mathrm{a}} \pm 0.096$ & \\
\hline H2 (Dina 2) & $26.7^{\mathrm{b}} \pm 0.088$ & \\
\hline H3 (Samy Asaad) & $23.7^{\mathrm{c}} \pm 0.108$ & \\
\hline H4 (EL-Karada) & $11.5^{\mathrm{d} \pm 0.204}$ & \\
\hline Parity: & & $<0.0001$ \\
\hline 1 & $22.3^{\mathrm{d}} \pm 0.085$ & \\
\hline 2 & $23.8^{\mathrm{b}} \pm 0.111$ & \\
\hline 3 & $24.0^{\mathrm{ab}} \pm 0.140$ & \\
\hline 4 & $24.3^{\mathrm{a}} \pm 0.174$ & \\
\hline$\geq 5$ & $23.2^{\mathrm{c}} \pm 0.193$ & \\
\hline THI: & & $<0.0001$ \\
\hline$\leq 74$ & $24.0^{\mathrm{a}} \pm 0.060$ & \\
\hline$>74$ & $23.0^{\mathrm{b}} \pm 0.128$ & \\
\hline Year period $(\mathbf{R})$ : & & $<0.0001$ \\
\hline R1 (2000-2011) & $24.2^{\mathrm{a}} \pm 0.098$ & \\
\hline R2 (2012-2014) & $22.8^{\mathrm{b}} \pm 0.091$ & \\
\hline Herd x Parity & & $<0.0001$ \\
\hline Herd x THI & & $<0.0001$ \\
\hline Herd $x$ Year period & & $<0.0001$ \\
\hline Parity x THI & & $<0.0001$ \\
\hline Parity x Year period & & $<0.0001$ \\
\hline THI $x$ Year period & & $<0.0001$ \\
\hline
\end{tabular}

Means with different letters within column of each factor differ significantly at 5\% level.

\section{Interactions:}

All interactions among factors incorporated into the statistical model were highly significant $(\mathrm{P}<0.0001)$. The interaction between herd and parity is shown in Figure (4). TDMY continued to rise from the first parity to the fifth in $\mathrm{H} 1$, with the automated cooling system, and in $\mathrm{H} 4$ with no cooling system. The effective automated cooling system provides more comfortable micro-climate in H1. The markedly lower productivity of $\mathrm{H} 4 \mathrm{Holsteins}$ and their genetic structure may, also, be responsible for their better persistency with an increase in lactation order.

The herd $\mathrm{x}$ THI interaction indicated an unequally TDMY decline in studied herds as THI increased from $\leq 74$ to $>74$ (Figure 5). H1, with the automated cooling system, showed the minimum decline in TDMY.

With respect to the interaction of parity $\mathrm{x} T \mathrm{TI}$, the third parity showed the largest decline by increasing THI. This could be due to the coupled effect of level 
of productivity and physiological maturity Figure (6) (Brouček et al., 2009).

The interaction of parity $\mathrm{x}$ year period reduced significantly TDMY. All parities showed lower TDMY in R2, however, the rate of decline was markedly different among parities (Figure 7). The most decline observed was that for parities $\geq 5$ and for parities <3. It should be mentioned that, longevity of Holsteins in Egypt is markedly shorter than its corresponding value in temperate areas (Samoul, 2011).
Interaction between THI $\mathrm{x}$ year period is quite obvious in Figure (8). TDMY declined drastically in R2. This may be due to the occurrence of marked climate change in R2.

The results elaborate the recommendation of Thornton et al. (2009), who stated that "the agenda of research and development organizations may need to adjustment if the needs of variable livestock keepers in the coming decades are to be effectively met".

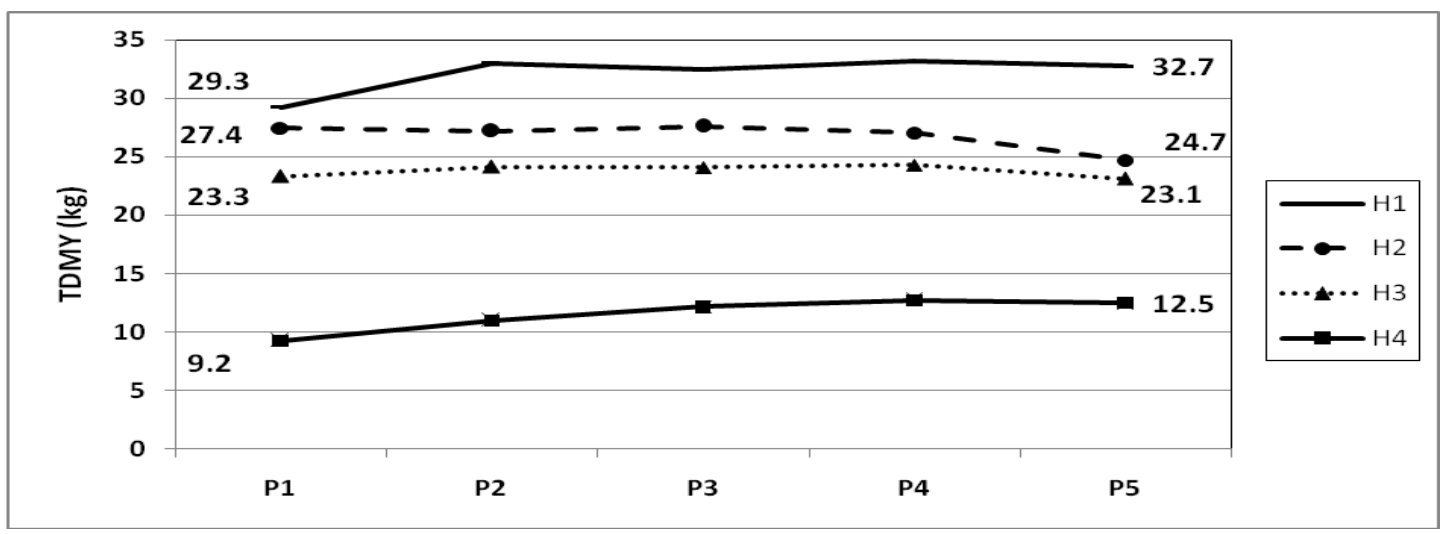

Fig. 4. Effect of the interaction between herd $(\mathrm{H})$ and parity $(\mathrm{P})$ on test day milk yield (TDMY).

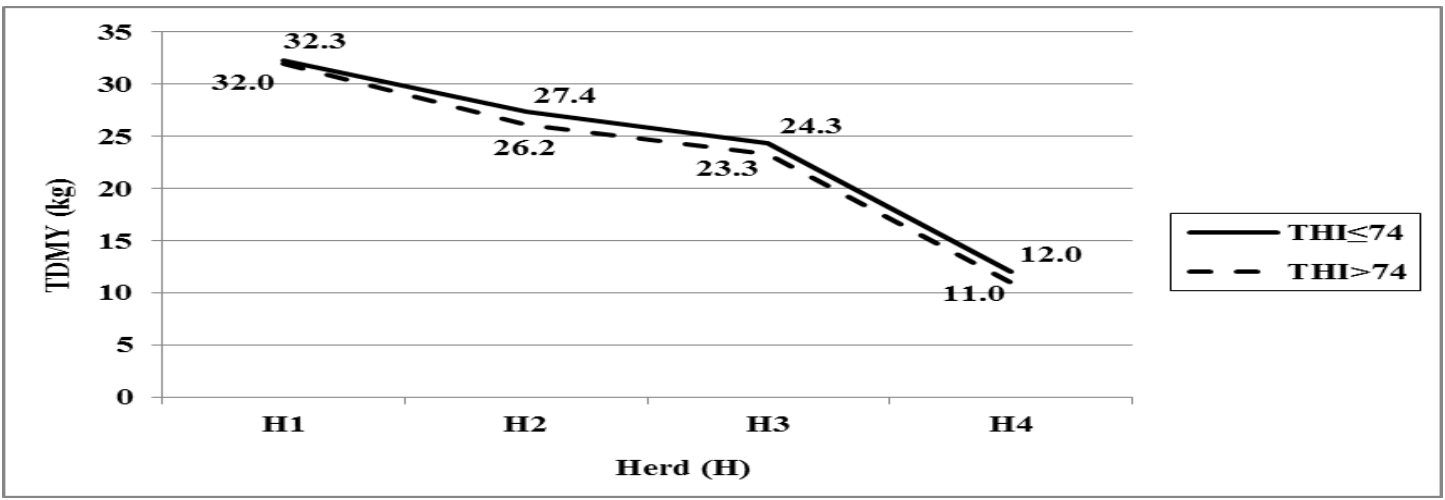

Fig. 5.Effect of the interaction between herd (H) and temperature humidity index (THI) on test day milk yield (TDMY).

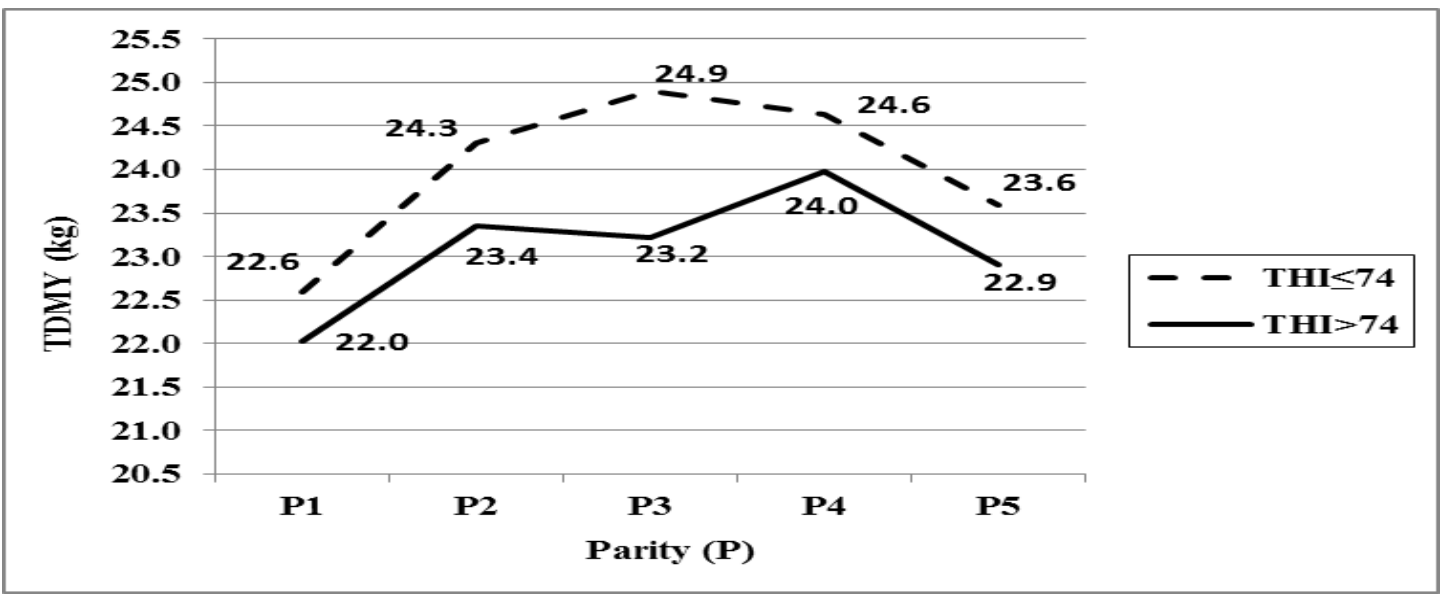

Fig. 6. Effect of the interaction between parity (P) and temperature humidity index (THI) on test day milk yield (TDMY). 


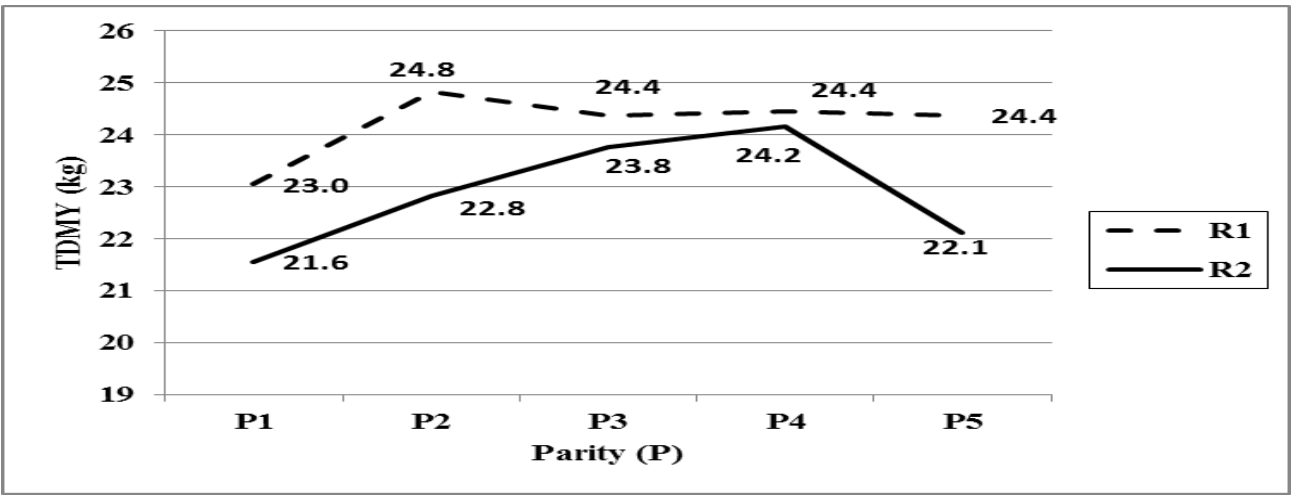

Fig. 7. Effect of the interaction between parity (P) and year period (R) on test day milk yield (TDMY).

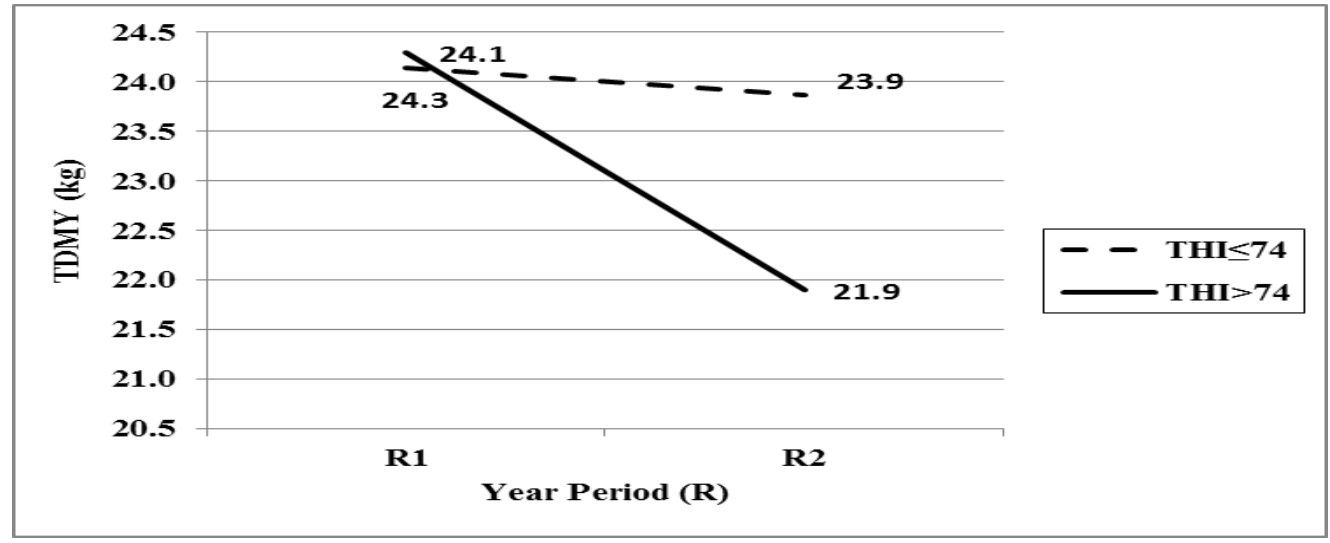

Fig. 8. Effect of the interaction between temperature humidity index (THI) and year period (R) on test day milk yield (TDMY).

\section{CONCLUSION}

Results obtained from the present study confirmed a marked change in climate of the Delta region of Egypt, expressed in the rise of temperature humidity index (THI) values. This rise started the year 2011 up to 2014. This change negatively affects milk production as measured by test-day milk yield (TDMY). Further studies are needed to analyse such effect on reproductive performance and longevity of Holstein cows if this rise in air temperature will continue. Also, the effect of climate change on buffalo and native cattle is quite important, though expected to be markedly less than that happened with the less adapted temperate breed "Holstein".

\section{ACKNOWLEDGEMENT}

The authors would like to thank Dina farm for Agricultural Investment, Sami Asaad farm and ElKarada farm for supplying milk production data. Also, the authors would like to thank the Central Laboratory for Agricultural Climate for supplying the meteorological data.

\section{REFERENCES}

Bohmanova, J., I. Misztal and J.B. Cole, 2006. Temperature-humidity indices as indicators of milk production losses due to heat stress. J. Dairy Sci., 90:1947-1956.
Brouček,J., P. Novák, J. Vokřálová, M. Šoch, P.Kišac and M. Uhrinčat', 2009.Effect of high temperature on milk production of cows from free-stall housing with natural ventilation. Slovak J. Anim. Sci., 42(4):167-173.

Elbeltagy, A.R., A.M. Aboul-Naga, H.H. Khalifa, T.M.M. Abdel Khalek, M.H. Elshafie and B. Rischovesky, 2015. Biological and

mathematical analysis of desert sheep and goats to both natural and acute heat stress in Egypt. Egyptian J. Anim. Prod., 52(1), In Press.

Elischer, M., 2014. History of dairy cow breeds Holstein.

http://msue.anr.msu.edu/news/history_of_dair y_cow_breeds_holstein.

Ericksson, L., E. Johansson, N. Kettaneh-Wold and S. Wold, 2001.Multi- and Megavariate Data Analysis.Principles and Applications, Umetrics Academy, Umea.

Guler, O., M. Yanar, R. Aydin, B. Bayram, U. Dogru and S. Kopuslu, 2009.Genetic and environmental parameters of milk ability traits in Holstein Friesian cows. J. Anim. Vet. Adv., 8(1):143-147.

Hafez, Y.M. , M.O. Taki, A.A. Baiomy, M.A. Medany and S. Abou-Bakr, 2011. Physiological and hormonal responses of Egyptian buffalo to different climatic 
conditions. Egyptian J. Anim. Prod., 48, Suppl. Issue: 61-73.

Hounghton, J.T., Y. Ding, D.J. Griggs, M. Noguer, P.J. van der Linden, X. Dai, K. Maskell and C.A. Johnson, 2001. Climate Change: The Scientific Basis. Contribution of Working Group I to the Third Assessment Report of the Intergovernmental Panel on Climate Change. Cambridge University Press, New York, USA.

Kaygisiz, A., 2013.Estimation of genetic parameters and breeding values for dairy cattle using testday milk yield records. J. Anim. Plant Sci., 23(2):345-349.

Mader, T.L., M.S. Davis and T. Brown-Brandl, 2006. Environmental factors influencing heat stress in feedlot cattle. J. Anim. Sci., 84:712719.

Marai,I.F.M., A.A. El-Darawany, A. Fadiel and M.A.M. Abdel-Hafez, 2008.Reproductive performance traits as affected by heat stress and its alleviation in sheep-a review. Trop. Subtrop. Agroecosys., 8:209-234.

Metzger, M.J., M.D.A. Rounsevell, L. AcostaMichlik, R. Leemans and D. Schroter, 2006. The vulnerability of ecosystem services to land use change. Agric. Ecosys. Envi., 114:69-85.

Nardone, A., B. Ronchi, N. Lacetera and U. Bernabucci, 2006.Climate effects on productive traits in livestock. Vet. Res. Commun., 30:75-81.

Nesamvuni, E., R. Lekalakala, D. Norris and J.W. Ngambi, 2012.Effects of climate change on dairy cattle, South Africa. African J. Agric. Res., 7(26):3867-3872.

NRC, 2001.Effect of environment on nutrient requirements of domestic animals. Natl. Acad. Sci., Washington, DC.

Olesen, J.E. and M. Bindi, 2002. Consequences of climate change for European agricultural productivity, land use and policy. European J. Agron., 16:239-262.

Perkins, S., 2012.Latest news earth warming faster than

expected.http://news.sciencemag.org/2012/03/ earth-warming-faster-expected.

Rhoads, M.L., J.W. Kim, R.J. Collier, B.A. Crooker, Y.R. Boisclair, L.H. Baumgard and R.P. Rhoads, 2010. Effects of heat stress and nutrition on lactating Holstein cows: II. Aspects of hepatic growth hormone responsiveness. J. Dairy Sci., 93(10):170-179.

Rhoads, M.L., R.P. Rhoads, M.J. VanBaale, R.J. Collier, S.R. Sanders, W.J. Weber, B.A. Crooker and L.H. Baumgard, 2009. Effects of heat stress and plane of nutrition on lactating Holstein cows: I. Production, metabolism, and aspects of circulating somatotropin.J. Dairy Sci., 92(5):1986-1997.

Ríos-Utrera, Á., R.C. Calderón-Robles, J.R. Galavíz-Rodríguez, V.E. Vega-Murillo and J. Lagunes-Lagunes, 2013. Effects of breed, calving season and parity on milk yield, body weight and efficiency of dairy cows under subtropical conditions. Int. J. Anim. Vet. Adv., 5(6):226-232.

Samoul, A.M., 2011. Impact of different housing systems on Friesian cattle performance.M.Sc. Thesis, Fac. Agric., Cairo Univ., Giza, Egypt.

Santos, D.J.A., M.G.C.D. Peixoto, R.R.A. Borquis, R.S. Verneque, J.C.C. Panettoand H. Tonhati, 2013. Genetic parameters for test-day milk yield, 305-day milk yield, and lactation length in Guzerat cows. Livest. Sci., 152:114-119.

Singh, S.K., H.R. Meena, D.V. Kolekar and Y.P. Singh, 2012. Climate change impacts on livestock and adaptation strategies to sustain livestock production. J. Vet. Adv., 2(7):407412.

Thornton, P.K., J. Van de Steeg, A. Notenbaert and M. Herrero, 2009. The impacts of climate change on livestock and livestock systems in developing countries: A review of what we know and what we need to know. Agric. Sys., 101:113-127.

West, J.W., 2003. Effects of heat stress on production in dairy cattle. J. Dairy Sci., 86:2131-2144.

Wheelock, J.B., R.P. Rhoads, M.J. VanBaale, S.R. Sanders and L.H. Baumgard, 2010. Effects of heat stress on energetic metabolism in lactating Holstein cows. J. Dairy Sci., 93(2):644-655.

Wolfenson, D., 2009. Impact of heat stress on production and fertility of dairy cattle. Proceedings of the $18^{\text {th }}$ Annual Tri-State Dairy Nutrition Conference, 21-22 April, 2009, Fort Wayne, Indiana, USA, pp.55-59.

Wolfenson, D., Z. Roth and R. Meidan, 2000. Impaired reproduction in heat-stressed cattle: basic and applied aspects. Anim. Reprod. Sci., 60-61:535-547.

Wold, S., 1995.PLS for multivariate linear modeling. In: Van de Waterbeemd H. (ed.), QSAR: Chemometric Methods in Molecular Desaign. Vol. 2. Wiley-VCH, Weinheim, Germany.pp.195-218.

XLSTAT, 2015.Statistical software for MS ExcelStatistical and data analysis with MS Excel.Addinsoft.

Yirka, B., 2012. New simulation predicts higher average earth temperatures by 2050 than other models. http://phys.org/news/2012-03simulation-higher-average-earthtemperatures.html. 
تأثير التغيرات المناخيه على إنتاج لبن يوم الإختبار لأبقار الهولثتين المرباه فى دلتا النيل بمصر على عطيه نجم'، ربيع رجب صادق'، شرين عبد الرحمن يس'، محمد عبد العزيز ابراهيم'، محمد عبدالعزيز الوردانىى '، '،

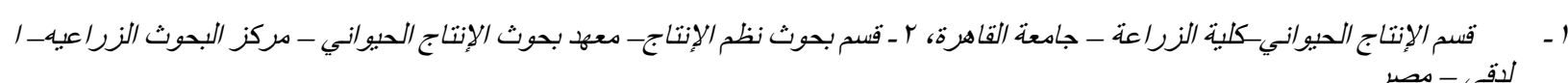

استهدفت هذه الدر اسه رصد التغير ات المناخيه وتقييم تأثير ها على إنتاج اللبن من أبقار الهولثتين في دلتا مصر . توفرت بيانات الأرصاد الجويه

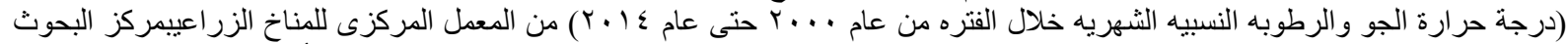

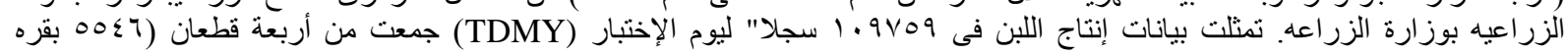

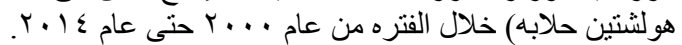

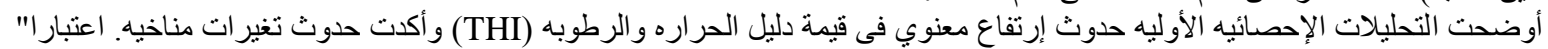

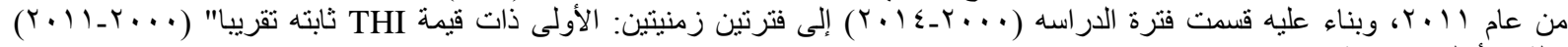

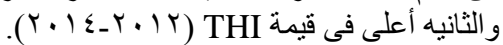

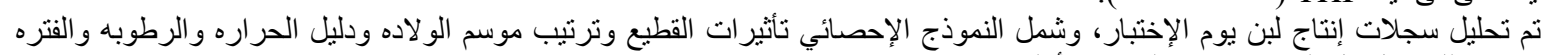

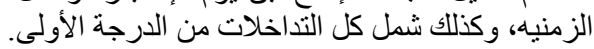

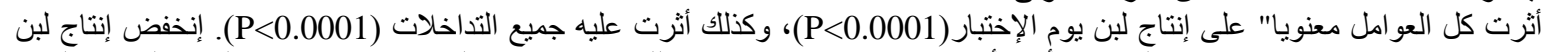

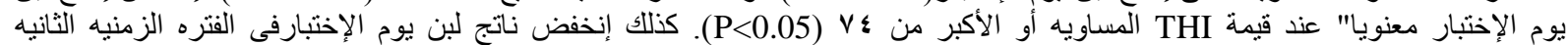

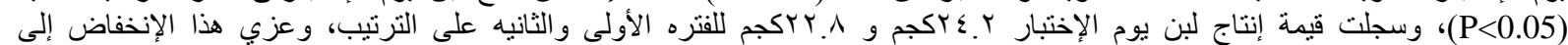

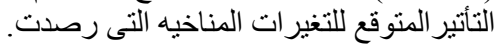

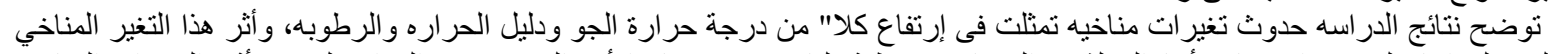

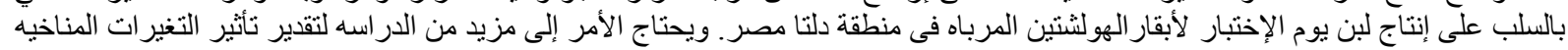
على صفات التناسل و الحيو لئ خصوم الإخبار لابفار في السلالات المحلين. 